\title{
PENGEMBANGAN E-MODUL BERBASIS PROJECT BASED LEARNING PADA MATA PELAJARAN ADMINISTRASI BASIS DATA KELAS XII REKAYASA PERANGKAT LUNAK DI SMK NEGERI 2 TABANAN
}

\author{
Putu Permana Putra'), I Made Agus Wirawan²), I Gede Partha Sindu ${ }^{3)}$ \\ ${ }^{1}$ Fakultas Teknik dan Kejuruan, Universitas Pendidikan Ganesha (penulis 1) \\ email: 1215051034@undiksha.ac.id \\ ${ }^{2}$ Fakultas Teknik dan Kejuruan, Universitas Pendidikan Ganesha (penulis 2) \\ email: imade.aguswirawan@undiksha.ac.id \\ ${ }^{3}$ Fakultas Teknik dan Kejuruan, Universitas Pendidikan Ganesha (penulis 3) \\ email: partha.sindu@undiksha.ac.id
}

\begin{abstract}
Abstrak
Tujuan penelitian ini adalah (1) Untuk mengimplementasikan Pengembangan E-modul Pada Mata Pelajaran Administrasi Basis Data Kelas XII Rekayasa Perangkat Lunak di SMK Negeri 2 Tabanan. (2) Untuk mengetahui respon siswa dan guru terhadap Pengembangan E-modul Pada Mata Pelajaran Administrasi Basis Data Kelas XII dengan Model Project Based Learning di SMK Negeri 2 Tabanan.

Metode penelitian yang digunakan dalam penelitian ini adalah research and development (R\&D), dengan model pengembangan ADDIE. Subjek penelitian ini yaitu siswa kelas XII Rekayasa Perangkat Lunak dan guru mata pelajaran Administrasi Basis Data di SMK Negeri 2 Tabanan tahun ajaran 2016/2017. Untuk mengetahui respon siswa dan guru terhadap e-modul diperoleh dengan menggunakan metode angket. Hasil penelitian menunjukkan bahwa: 1) Hasil implementasi e-modul yang telah dikembangkan pada mata pelajaran basis data untuk siswa kelas XII Rekayasa Perangkat Lunak dengan menggunakan model pembelajaran Project Based Learning di SMK Negeri 2 Tabanan dinyatakan berhasil diterapkan berdasarkan beberapa uji yang dilakukan. 2) Hasil analisis data respon siswa menunjukkan bahwa persentase siswa yang memberikan respon sangat baik sebesar $50 \%$, persentase siswa yang memberikan respon baik sebesar $50 \%$, dan tidak ada siswa yang memberikan respon cukup, kurang, maupun sangat kurang.

Sedangkan hasil analisis data respon guru menunjukkan bahwa persentase guru yang memberikan respon sangat baik sebesar $100 \%$, dan tidak ada guru yang memberikan respon baik, cukup, kurang, maupun sangat kurang.
\end{abstract}

Kata kunci: E-modul, Administrasi Basis Data, Model Project Based Learning

Abstract
The aim of this study is to (1) Implement the development of E-module for Database Administration learning lesson of grade XII with Project Based Learning Model in SMK Negeri 2 Tabanan. (2) To know students' and teachers' response towards the development of E-module for Database Administration learning lesson of grade XII with Project Based Learning Model in SMK Negeri 2 Tabanan.

Research methodology that is used for this research was Research and Development (R\&D), with ADDIE development model. The subject of this research was the third grade students, engineer software and Data Basis Administration teachers of SMK Negeri 2 Tabanan in Academic Year 2016/2017. To know students' and teachers' response towards the E-module was gained by using inquiry method. The result of this study showed that: (1) Implementation result of E-module which was developed for Database Administration learning lesson of grade XII engineer software by using Project Based Learning Model in SMK Negeri 2 Tabanan has proven effective to be applied through some tests. (2) The data analysis result of students' response showed that the percentage of students' who give excellent response was $50 \%$, students who gave good response were $50 \%$, and there were no students who gave fair response, inadequate and inacceptable response. 
While the data analysis result of teachers' response showed that the percentage of teaches who gave excellent response was $100 \%$ and there were no teachers who gave good, fair, inadequate and inacceptable response.

Keywords: E-Module, database administration, project based learning

\section{PENDAHULUAN}

SMK Negeri 2 Tabanan merupakan sekolah menengah kejuruan yang senatiasa berupaya untuk meningkatkan mutu dari segala aspek sehingga diharapkan nantinnya akan memberikan dampak terhadap lulusan yang mempunyai kualitas kompetensi yang siap bersaing di dunia kerja dan mampu mengembangkan sikap profesional di bidangnya. Dalam menyiapkan lulusan yang mempunyai kompetensi yang baik kendala yang dihadapi masing-masing jurusan yang ada di SMK Negeri 2 Tabanan contohnya jurusan Rekayasa Perangkat Lunak yang menghadapi permasalahan kurangnya sumber dan media yang menunjang proses belajar mengajar.

Berdasarkan observasi awal yang dilakukan dengan wawancara beserta angket terhadap guru pengampu mata pelajaran administrasi basis data $\mathrm{Ni}$ Wayan Pusri, S.Kom diperoleh data bahwa belum adanya sumber belajar ataupun bahan ajar yang dipakai dalam kegiatan belajar mengajar. Sekalipun ada hanya sekedar materi lepasan yang didapat dari materi perkuliahan, sehingga kegiatan belajar mengajar siswa terpaku pada penjelasan guru. Hal ini menyebabkan siswa menjadi terbatas untuk melakukan pengembangan diri dengan potensi yang dimiliki sesuai dengan bidang keahliannya. Sejalan dengan observasi kegiatan belajar mengajar, model pembelajaran yang biasanya digunakan adalah model pembelajaran konvensional. Materi pelajaran diberikan oleh guru dengan metode ceramah. Kelemahan dari model pembelajaran ini yaitu tidak semua siswa mau mendengarkan penjelasan guru. Hanya siswa yang memiliki kemauan dan rasa ingin tahu yang akan mendengarkan penjelasan guru.
Sekitar $90 \%$ siswa mau memperhatikan ketika guru menjelaskan dan sekitar $10 \%$ siswa kurang memperhatikan penjelasan guru. Untuk ketuntasan nilai, guru menggunakan sistem remidi. Jadi siswa yang memiliki nilai dibawah KKM akan diremidi dan akan mendapatkan nilai sesuai dengan standar KKM. Setelah angket disebar ke siswa kelas XII rekayasa perangkat lunak didapat hasil sebagian besar siswa mengatakan perlu dikembangkannya $e$ modul. Sebagian besar dari siswa mengatakan perlu sumber belajar yang menyajikan materi secara menarik dan komunikatif dimana materi yang disampaikan bukan hanya berupa teks namun juga berupa gambar bergerak atau video sehingga bisa menarik minat siswa dalam proses pembelajaran.

Dalam pembuatan e-modul yang dirancang dengan moodle ini nantinya akan disediakan fitur-fitur yang menunjang aktivitas siswa yang belajar dengan menerapkan model pembelajaran Project based learning. Pada tahap (eksplorasi) orientasi masalah, merencanakan laporan, (konfirmasi) presentasi laporan, dan evaluasi akan dibantu dengan fitur Assignments dimana dengan aktifitas ini, teacher dapat memberikan tugas yang mengharuskan student mengirim (upload) konten digital, misalnya essay, tugas proyek, laporan, dan lain-lain, Jenis file yang dapat dikirim misalnya ordprocessed documents, spreadsheets, images, audio and video clips. Selanjutnya teacher dapat melihat dan menilai tugas yang telah dikirim oleh student. Pada tahap membentuk kelompok dan merencanakan kegiatan kelompok dan (elaborasi) melakukan investigasi akan dibantu dengan fitur Chat dimana dengan menggunakan aktivitas ini, setiap peserta dapat berdiskusi secara real-time via web sehingga siswa bisa berdiskusi dengan anggota kelompoknya terkait solusi yang 
akan diberikan terhadap permasalahan yang ada.

Berdasarkan uraian diatas, tujuan dari penelitian ini adalah mengembangkan bahan ajar berupa e-modul berbasis

\section{KAJIAN TEORI}

A. Mata Pelajaran Administrasi Basis Data Mata pelajaran administrasi basis data merupakan salah satu mata pelajaran yang ada di program keahlian Rekayasa Perangkat Lunak. Administrasi basis data diajarkan di kelas XII selama satu tahun yaitu pada semester ganjil dan semester genap. Mata pelajaran administrasi basis data terbilang baru, karena mata pelajaran ini mulai ada sejak digunakannya kurikulum 2013 di sekolahsekolah. Pada mata pelajaran administrasi basis data kelas XII, terdapat 11 kompetensi dasar ialah Memahami arsitektur DBMS enterprise, Memahami pembuatan basis data pada DBMS enterprise, Menganalisis pengaturan DBMS enterprise, Memahami struktur penyimpanan pada DBMS enterprise, Memahami pengelolaan obyek-obyek primer pada DBMS enterprise, Menerapkan penggunaan alat bantu untuk mengelola sistem DBMS enterprise, Menerapkan pengendalian server melalui koneksi client-server pada DBMS enterprise, Menerapkan pengamanan sistem basis data pada DBMS enterprise, Menerapkan pengelolaan data dan sistem menggunakan bahasa procedural SQL, Menerapkan otomatisasi proses pengelolaan data, dan Memahami perawatan basis data.

\section{B. Perangkat Pembelajaran}

Perangkat pembelajaran merupakan hal yang harus disiapkan oleh guru sebelum melaksanakan pembelajaran. Menurut Zuhdan, dkk (2011:16) Perangkat pembelajaran adalah alat atau perlengkapan untuk melaksanakan proses yang memungkinkan pendidik dan peserta didik melakukan kegiatan pembelajaran. Perangkat pembelajaran menjadi pegangan bagi guru dalam melaksanakan pembelajaran baik di kelas, laboratorium atau di luar kelas. Dalam Permendikbud project based learning pada mata pelajaran Administrasi Basis Data Kelas XII Rekayasas Perangkat Lunak di SMK Negeri 2 Tabanan.

No. 65 Tahun 2013 tentang Standar Proses Pendidikan Dasar dan Menengah disebutkan bahwa penyusunan perangkat pembelajaran merupakan bagian dari perencanaan pembelajaran. Perencanaan pembelajaran dirancang dalam bentuk silabus dan RPP yang mengacu pada standar isi. Selain itu, dalam perencanaan pembelajaran juga dilakukan penyiapan media dan sumber belajar, perangkat penilaian, dan skenario pembelajaran.

Peraturan Menteri Pendidikan dan Kebudayaan Republik Indonesia No. 65 Tahun 2013 Tentang Standar Proses Pendidikan Dasar dan Menengah menjelaskan bahwa silabus merupakan acuan penyusunan kerangka pembelajaran untuk setiap bahan kajian mata pelajaran. Silabus dikembangkan berdasarkan Standar Kompetensi Lulusan dan Standar Isi untuk satuan pendidikan dasar dan menegah sesuai dengan pola pembelajaran pada setiap tahun ajaran tertentu.

Menurut Permendikbud No. 81A Tahun 2013 tentang Implementasi Kurikulum Pedoman Umum Pembelajaran, bahwa tahap pertama dalam pembelajaran menurut standar proses yaitu perencanaan pembelajaran yang diwujudkan dengan kegiatan penyusunan Rencana Pelaksanaan Pembelajaran (RPP). Selanjutnya dijelaskan bahwa RPP adalah rencana pembelajaran yang dikembangkan secara rinci dari suatu materi pokok atau tema tertentu yang mengacu pada silabus.

LKS adalah lembaran yang berisi tugas yang harus dikerjakan oleh siswa. Tugas yang diperintahkan dalam LKS harus mengacu pada kompetensi dasar yang akan dicapai siswa. Tugas tersebut dapat berupa tugas teoritis dan tugas praktis (Abdul Majid, 2008:176-177.

Penilaian bertujuan untuk mengumpulkan informasi tentang kemajuan belajar peserta didik. Dalam 
Permendikbud No. 81A Tahun 2013 tentang Implementasi Kurikulum Pedoman Umum Pembelajaran dijelaskan bahwa penilaian dalam setiap mata pelajaran meliputi kompetensi pengetahuan, kompetensi keterampilan dan kompetensi sikap.

\section{Teori Belajar Konstruktivisme}

Menurut teori konstruktivisme, yang menjadi dasar bahwa siswa memperoleh pengetahuan adalah karena keaktifan siswa itu sendiri. Menurut Putrayasa (2011), belajar menurut pandangan konstruktivis lebih diarahkan pada terbentuknya makna pada diri pemelajar atas apa yang dipelajarinya berdasarkan pengetahuan dan pemahaman mereka sebelumnya. Dalam proses ini lebih ditekankan pada terbentuknya hubunganhubungan makna antara pengetahuan yang telah ada dan pengetahuan baru dengan fasilitasi kreativitas guru selaku mediator pembelajaran. Dengan demikian, dilihat dari dimensi pembelajaran, model konstruktivis memandang belajar itu sebagai sebuah proses modifikasi ide dan pengetahuan yang telah dimiliki oleh siswa menuju terbentuknya pengetahuan baru. Dalam proses ini siswa secara aktif terlibat dalam upaya penemuan makna dari apa yang dipelajarinya, sehingga secara langsung berdampak pada tumbuh dan berkembangnya keterampilan berpikir mereka selama pembelajaran berlangsung). Di samping itu, aplikasi model konstruktivis memungkinkan siswa untuk menguasai materi pelajaran secara lebih komprehensif dan bermakna, mengingat mereka terlibat secara aktif selama berlangsungnya pembelajaran.

\section{Model Pembelajaran Project Based Learning \\ Menurut Santyasa \& Sukadi} (2007:9), Project-Based Learning berisi 6 fase utama yang dimulai dengan orientasi masalah yang disampaikan guru untuk mengarahkan siswa tentang situasi masalah dan membentuk kelompok, melakukan investigasi, merencanakan laporan, presentasi laporan, dan evaluasi. Jika ruang lingkup masalah yang diberikan sempit, maka 6 fase dapat diselesaikan dalam satu periode di kelas, namun jika ruang lingkup masalah luas dan kompleks, mungkin memerlukan waktu yang lebih banyak.

\section{E. Bahan Ajar}

Bahan ajar merupakan salah satu bagian penting dalam proses pembelajaran. Sebagaimana Mulyasa (2005) mengemukakan bahwa bahan ajar merupakan salah satu bagian dari sumber ajar yang dapat diartikan sesuatu yang mengandung pesan pembelajaran, baik yang bersifat khusus maupun yang bersifat umum yang dapat dimanfaatkan untuk kepentingan pembelajaran. Pengertian ini menggambarkan bahwa bahan ajar hendaknya dirancang dan ditulis sesuai dengan kaidah pembelajaran, yakni disesuaikan materi pembelajaran, disusun berdasarkan atas kebutuhan pembelajaran, terdapat bahan evaluasi, serta bahan ajar tersebut menarik untuk dipelajari oleh siswa.

Menurut Widodo dan Jasmadi (dalam Lestari, 2013:2), bahan ajar memiliki 5 (lima) karakteristik yaitu (1) Self instructional, bahan ajar yang dirancang dapat digunakan secara mandiri oleh siswa di dalam proses pembelajaran, (2) Self contained, bahan ajar yang tersaji untuk dipelajari siswa berisi seluruh materi pelajaran dalam satu unit kompetensi dan sub kompetensi, (3) Stand alone, bahan ajar tersebut tidak bergantung dengan bahan ajar lain, (4) Adaptive, dapat beradaptasi dengan teknologi mutakhir, dan (5) User friendly, memudahkan pengguna dan memberi kesan bersahabat baik secara tampilan maupun fungsi dalam penggunaannya.

\section{F. Modul}

Salah satu bahan ajar cetak yang masih bertahan penggunaannya dan mampu bersaing dengan bahan ajar lain sampai saat ini adalah modul. Modul adalah bahan ajar yang disusun secara sistematis dan menarik yang mencakup isi materi, metode dan evaluasi yang dapat digunakan secara mandiri untuk mencapai 
kompetensi yang diharapkan (Anwar, 2010).

Sebuah modul bisa dikatakan baik dan menarik apabila terdapat karakteristik sebagai berikut (Anwar, 2010): (1) Self instructional, Siswa mampu membelajarkan diri sendiri, tidak tergantung pada pihak lain. (2) Self contained, Seluruh materi pembelajaran dari satu unit kompetensi yang dipelajari terdapat didalam satu modul utuh. (3) Stand alone, Modul yang dikembangkan tidak tergantung pada media lain atau tidak harus digunakan bersama-sama dengan media lain. (4) Adaptif, Modul hendaknya memiliki daya adaptif yang tinggi terhadap perkembangan ilmu dan teknologi. (5) User friendly, Modul hendaknya juga memenuhi kaidah akrab bersahabat/akrab dengan pemakainya, dan Konsistensi, Konsisten dalam penggunaan font, spasi, dan tata letak.

G. Modul Elektronik (E-Modul)

Menurut Wijayanto(2014), Modul elektronik atau e-modul merupakan tampilan informasi dalam format buku yang disajikan secara elektronik dengan menggunakan harddisk, disket, $C D$, atau flashdisk dan dapat dibaca dengan menggunakan komputer atau alat pembaca buku elektronik.

Dimhad (2014) mengemukakan Emodul adalah bagian dari electronic based e-learning yang pembelajarannya memanfaatkan teknologi informasi dan komunikasi, terutama perangkat berupa elektronik. Artinya tidak hanya internet, melainkan semua perangkat elektronik seperti film, video kaset, OHP, slide, LCD projector, tape set.

Menurut Fnurma dalam (Fausih, 2015), E-modul merupakan alat atau sarana pembelajaran yang berisi materi, metode, batasan-batasan, dan cara mengevaluasi yang dirancang secara sistematis dan menarik untuk mencapai kompetensi yang diharapkan sesuai dengan tingkat kompleksitasnya secara elektronik.

Dari beberapa pendapat tersebut dapat ditarik kesimpulan bahwa e-modul adalah seperangkat media pengajaran digital atau non cetak yang disusun secara sistematis yang digunakan untuk keperluan belajar mandiri. Sehingga menuntu siswa untuk belajar memecahkan masalah dengan caranya sendiri.

\section{H. Media Pembelajaran CAI (Computer Assisted Instruction) \\ CAI (Computer-Assisted Instruction)} yaitu penggunaan komputer secara langsung dengan siswa untuk menyampaikan isi pelajaran, memberikan latihan dan mengetes kemajuan belajar siswa. Komputer dapat mengajarkan konsep-konsep aturan, prinsip, langkahlangkah, proses, dan kalkulasi yang kompleks. Sehingga cocok untuk kegiatan pemebelajaran mandiri (Megawati, 2010).

\section{Perangkat Lunak Moodle} Moodle (Modular Object-Oriented Dynamic Learning Environment) merupakan salah satu aplikasi LMS (Learning Management System) berbasiskan web yang paling populer dan banyak dipakai untuk membangun aplikasi e-learning. Moodle merupakan software open-source jadi disediakan secara bebas, dapat diinstall dan dikembangkan dengan gratis.

\section{J. Kerangka Berpikir}

Berdasarkan kajian teoretis dan penelitian yang relevan, langkah-langkah yang dilakukan dalam pengembangan $e-$ modul secara umum adalah Melakukan studi pendahuluan, Mengidentifikasi kebutuhan/tujuan umum pembelajaran, Melakukan analisis pembelajaran, Mengembangkan dan memilih material pembelajaran, Merancang dan membangun e-modul, dan Uji coba.

Kerangka berpikir pengembangan $e$ modul berbasis project based learning pada mata pelajaran administrasi basis data diatas dapat digambarkan kerangka seperti ditunjukkan pada gambar: 


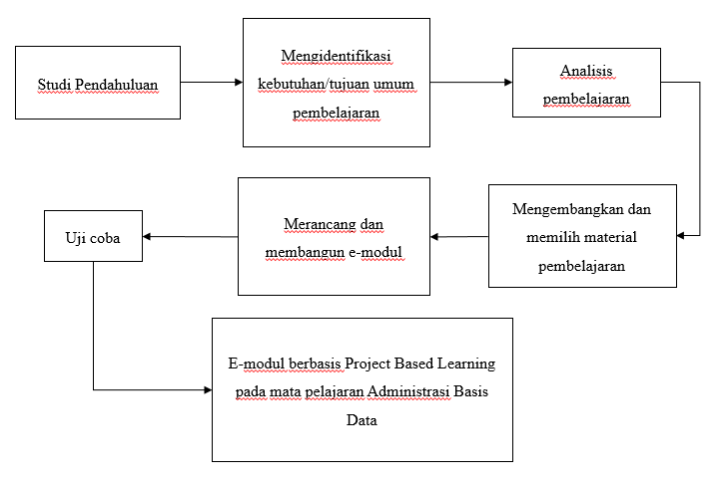

Gambar 1. Kerangka berpikir pengembangan e-modul

\section{METODE}

Penelitian ini merupakan jenis penelitian pengembangan atau research and development (R\&D). Metode pengembangan merupakan cara yang digunakan untuk menemukan, mengembangkan dan menguji suatu produk berdasarkan prosedur yang sistematis, sehingga produk yang dihasilkan memiliki nilai ilmiah yang tinggi dan dapat dipercaya. Produk yang dimaksud berupa modul elektronik dalam bentuk web yang digunakan sebagai media pembelajaran administrasi basis data kelas XII. Jenis penelitian ini dipilih karena prosedur yang ada di dalamnya sangat tepat untuk melakukan penggembangan sebuah media yang mempunyai tujuan untuk mengembangkan dan memvalidasi produk.

Model pengembangan e-modul ini menggunakan model pengembangan ADDIE, dimana model pengembangan ini terdiri dari 5 tahapan yaitu Analysis (analisis), Design (desain), Development (pengembangan), Implementation (implementasi) dan Evaluation (evaluasi). Model ini dipilih karena model pengembangan instruksional ini bisa digunakan untuk membantu menyelesaikan permasalahan pembelajaran yang komplek dan juga mengembangkan produk-produk pendidikan dan pembelajaran. Model ADDIE merupakan model pembelajaran yang bersifat umum dan sesuai digunakan untuk penelitian pengembangan. Dalam penelitian ini digunakan instrumen berupa angket untuk mengumpulkan data yang dibutuhkan terkait informasi tentang sumber belajar, karakteristik siswa, uji kevalidan e-modul, serta uji respon guru dan siswa terhadap e-modul yang dikembangkan. Teknik pengumpulan data dapat dilihat pada tabel berikut.

Tabel 1. Teknik Pengumpulan Data

\begin{tabular}{llll}
\hline No & Jenis Data & Metode & Sumber data \\
\hline 1 & $\begin{array}{l}\text { Informasi } \\
\text { tentang }\end{array}$ & Angket & $\begin{array}{l}\text { Guru mata pelajaran administrasi } \\
\text { basis data dan peserta didik kelas XII }\end{array}$ \\
& $\begin{array}{l}\text { sumber belajar } \\
\text { Karakteristik } \\
\text { siswa }\end{array}$ & Angket & $\begin{array}{l}\text { RPL di SMKN 2 Tabanan } \\
\text { Peserta didik kelas XII RPL di SMKN }\end{array}$ \\
3 & $\begin{array}{l}\text { Kevalidan E- } \\
\text { modul }\end{array}$ & Angket & Ahli Isi Pembelajaran, Ahli Desain \\
4 & $\begin{array}{l}\text { Respon guru } \\
\text { dan siswa }\end{array}$ & Angket & $\begin{array}{l}\text { Guru mata pelajaran administrasi } \\
\text { basis data dan peserta didik kelas XII } \\
\text { RPL di SMKN 2 Tabanan }\end{array}$ \\
\hline
\end{tabular}

Pada kegiatan observasi guna mendapat informasi sumber belajar dan karakteristik pembelajar, digunakan jenis angket terbuka. Melalui metode angket ini peneliti mengetahui masalah yang terjadi ketika pembelajaran berlangsung terkait sumber belajar, materi, media, dan ketertarikan siswa dalam pembelajaran sistem komputer. Uraian singkat tentang teknis analisis data yang digunakan dalam penelitian ini adalah sebagai berikut. 
1. Validasi data e-modul

Penilaian persentase hasil yang diperoleh menggunakan rumus sebagai berikut.

Persentase $=\frac{\text { Skor Perolehan }}{\text { Skor Maksimal }} \times 100 \%$

Tabel 2. Konversi Tingkat Pencapaian Dengan Skala 5

\begin{tabular}{lll}
\hline Tingkat Pencapaian & Kualifikasi & Keterangan \\
\hline $90 \%-100 \%$ & Sangat baik & Tidak perlu direvisi \\
$75 \%-89 \%$ & Baik & Tidak perlu direvisi \\
$65 \%-74 \%$ & Cukup & Direvisi \\
$55 \%-64 \%$ & Kurang & Direvisi \\
$0 \%-54 \%$ & Sangat kurang & Direvisi \\
\hline
\end{tabular}

2. Analisis data respon guru dan siswa

Dalam melakukan perhitungan analisis data respon maka didasarkan pada ratarata kelas $(\bar{x})$ dari respon peserta didik, $\mathrm{Mi}$, dan SDi. Rata-rata kelas dari skor respon peserta didik dihitung dengan rumus.

$\bar{x}=\frac{\sum x}{N}$

Keterangan:

$\bar{x}=$ Rata - rata kelas untuk skor respon siswa

$\sum x=$ Jumlah skor respon siswa

$\mathrm{N}$ = Banyaknya siswa

Sedangkan untuk mencari mean ideal (Mi)
Untuk melihat tingkat pencapaian pengembangan e-modul berdasarkan perhitungan persentase maka ditetapkan kriteria sesuai tabel tingkat pencapaian seperti terlihat pada tabel berikut

Tabel 3. Konversi rata-rata kelas

\begin{tabular}{lll}
\hline No & Interval & Kategori \\
\hline 1 & $\mathrm{Mi}+1,5 \mathrm{SDi} \leq \bar{x}$ & Sangat Positif \\
2 & $\mathrm{Mi}+0,5 \mathrm{SDi} \leq \bar{x}<\mathrm{Mi}+1,5 \mathrm{SDi}$ & Positif \\
3 & $\mathrm{Mi}-0,5 \mathrm{SDi} \leq \bar{x}<\mathrm{Mi}+0,5 \mathrm{SDi}$ & Kurang Positif \\
4 & $\mathrm{Mi}-1,5 \mathrm{SDi} \leq \bar{x}<\mathrm{Mi}-1,5 \mathrm{SDi}$ & Negatif \\
5 & $\bar{x}<\mathrm{Mi}-1,5 \mathrm{SDi}$ & Sangat Negatif \\
\hline
\end{tabular}

\section{HASIL DAN PEMBAHASAN}

Pengembangan e-modul pada mata pelajaran administrasi basis data kelas XII memiliki tujuan untuk membantu siswa dalam menjalani proses pembelajaran di dalam kelas. Dari hasil analisis sumber belajar yang dilakukan, siswa belum menggunakan e-modul dalam proses belajar dan hanya bersumber kepada internet. Dengan demikian dan standar deviasi ideal (SDi) digunakan rumus sebagai berikut:

$\mathrm{Mi}=\frac{1}{2}($ skor maksimal + skor terendah $)$

$\mathrm{SDi}=\frac{1}{2}($ skor tertinggi + skor terendah $)$....

Rata-rata kelas $(\bar{x})$ dari skor respon kemudian dikategorikan dengan menggunakan pedoman pada tabel berikut. pengembangan e-modul administrasi basis data sangat diperlukan khususnya pada Program Keahlian Rekayasa Perangkat Lunak kelas XII di SMK Negeri 2 Tabanan.

Selain itu, e-modul ini dikembangkan dengan menggunakan model pembelajaran Project Based Learning dengan tujuan agar tahapan - tahapan 
pembelajaran yang ada didalam e-modul ini dapat terstruktur dan terarah. Sesuai dengan paparan hasil penelitian, berikut ini diuraikan pembahasan yang dilakukan. Pembahasan difokuskan pada penyajian dan analisis data serta revisi yang dilakukan terhadap objek pengembangan. Tahap pertama menentukan mata pelajaran yang menjadi objek penelitian yaitu mata pelajaran administrasi basis data. Tahap kedua yaitu menganalisis kebutuhan dari mata pelajaran administrasi basis data. Tahap ketiga adalah proses pengembangan draft, yaitu (a) analisis kondisi pembelajaran, (b) langkah pengembangan. Tahap keempat pengembangan media menggunakan model ADDIE, yang meliputi (1) analisis (analyze), (2) perancangan (design), (3) pengembangan (development), implementasi (implementation), dan (5) evaluasi (evaluation). Tahap Kelima adalah tahap terakhir dalam pengembangan e-modul administrasi basis data yaitu tinjauan ahli dan uji coba $e$ - modul.

Tahapan pertama yang dilakukan adalah menentukan mata pelajaran. Mata pelajaran yang digunakan dalam pengembangan e-modul ini adalah administrasi basis data untuk kelas XII.

Tahap kedua yaitu menganalisis kebutuhan. Analisis kebutuhan yang dilakukan adalah menganalisis media pembelajaran yang sesuai dengan karakteristik pebelajar dan mata pelajaran. Tatan (2012:79), menyatakan bahwa penggunaan media belajar yang refresentatif telah meningkatkan minat belajar siswa yang berdampak pada hasil belajar. Media pembelajaran yang ada yaitu menggunakan modul. Dengan mengikuti perkembangan zaman, kini modul sudah bertransformasi menjadi $e$ modul. Tidak hanya e-modul biasa, pengembangan e-modul ini juga disertai dengan model pembelajaran yang cocok dengan karakteristik pelajaran. Model pembelajaran yang diterapkan pada pengembangan e-modul mata pelajaran administrasi basis data yakni model pembelajaran Project Based Learning.

Tahap ketiga yang dilakukan adalah pengembangan e-modul menggunakan model pengembangan ADDIE. Pada tahap ADDIE, hal yang dilakukan adalah perancangan hingga pembuatan e-modul. Tahapan ADDIE meliputi menganalisis kondisi pembelajaran, yang kedua merancang antarmuka tampilan dan isi $e$ modul, ketiga adalah tahap pengembangan e-modul yaitu pemetaan model pembelajaran beserta isi pembelajaran ke e-modul dengan menggunakan fitur-fitur yang telah tersedia, yang keempat adalah implementasi dimana e-modul yang dibuat diujicobakan terlebih dahulu ke dosen ahli serta guru ahli, kemudian baru diimplementasikan ke sekolah dengan melakukan uji perorangan, uji kelopok kecil, uji lapangan, serta mengambil respon siswa melalui angket.

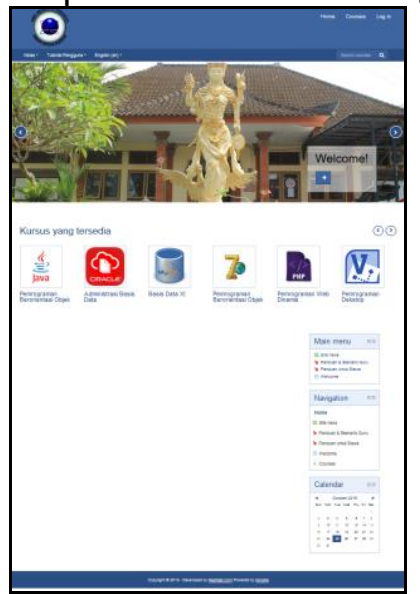

Gambar 2. Halaman Utama E-Modul

Hasil penilaian ahli isi berdasarkan angket sudah dinyatakan sesuai, hal tersebut mengindikasi materi yang ada di dalam e-modul layak untuk digunakan dalam pembelajaran administrasi basis data. Beberapa masukan dari ahli isi antara lain konsistensi cover dan font diperbaiki dan juga penulisan bahasa asing dimiringkan. 
Tabel 4. Rekapitulasi Penilaian Pada Uji Coba Perorangan

\begin{tabular}{lcc}
\hline $\begin{array}{c}\text { Konversi tingkat } \\
\text { pencapaian }\end{array}$ & $\begin{array}{c}\text { Persentase } \\
(\%)\end{array}$ & $\begin{array}{c}\text { Jumlah Responden } \\
\text { (orang) }\end{array}$ \\
\hline Sangat Baik & $0 \%$ & 0 \\
Baik & $100 \%$ & 3 \\
Cukup & $0 \%$ & 0 \\
Kurang & $0 \%$ & 0 \\
Sangat Kurang & $0 \%$ & 0 \\
\hline
\end{tabular}

Hasil penilaian dari ahli media adalah perhatikan ukuran font tertentu. Kemudian tambahkan fitur-fitur terbaru. Ahli media juga menyarankan untuk menyesuaikan jenis-jenis font di kotak tertentu.

Hasil penilaian dari ahli desain berupa rumusan project belum mencerminkan hakikat project based learning. Kemudian perbaiki tata tulis terutama istilah asing.

Setelah uji perorangan selesai, dilakukan tahap uji kelompok kecil dengan menggunakan 12 orang siswa. Dari hasil perhitungan, didapat tidak ada responden yang memberikan tanggapan sangat baik, 12 responden dengan perolehan 100\%
Setelah dilakukannya tahap uji oleh ahli, selanjutnya dilakukan uji perorangan dengan pengambilan 3 sampel (siswa). Dari hasil perhitungan uji perorangan di dapat tidak ada siswa yang memberikan tanggapan sangat baik, 3 siswa dengan perolehan $100 \%$ memberikan tanggapan baik dan tidak ada siswa yang memberikan tanggapan cukup, kurang maupun sangat kurang siswa memberikan tanggapan baik dan tidak ada yang memberikan tanggapan cukup, kurang dan sangat kurang.

Tabel 5. Rekapitulasi Penilaian Pada Uji Coba Kelompok Kecil

Konversi tingkat pencapaian $\quad$ Persentase (\%) Jumlah Responden (orang)

\begin{tabular}{lcc}
\hline Sangat Baik & $0 \%$ & 0 \\
Baik & $100 \%$ & 12 \\
Cukup & $0 \%$ & 0 \\
Kurang & $0 \%$ & 0 \\
Sangat Kurang & $0 \%$ & 0
\end{tabular}

Kemudian dilakukan uji lapangan dengan menggunakan 22 orang siswa. Dari hasil perhitungan, didapat 12 responden dengan perolehan $54,55 \%$ siswa memberikan tanggapan sangat baik, 10 responden dengan perolehan $45,45 \%$ siswa memberikan tanggapan baik dan tidak ada yang memberikan tanggapan cukup, kurang dan sangat kurang. 
Tabel 6. Rekapitulasi Penilaian Pada Uji Lapangan

\begin{tabular}{lcc}
\hline \multicolumn{1}{c}{ Konversi tingkat pencapaian } & Persentase (\%) & $\begin{array}{c}\text { Jumlah Responden } \\
\text { (orang) }\end{array}$ \\
\hline Sangat Baik & $54,55 \%$ & 12 \\
Baik & $45,45 \%$ & 10 \\
Cukup & $0 \%$ & 0 \\
Kurang & $0 \%$ & 0 \\
Sangat Kurang & $0 \%$ & 0 \\
\hline
\end{tabular}

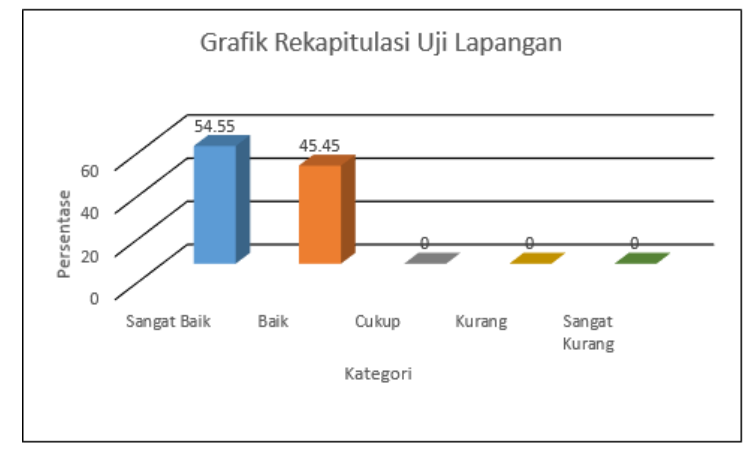

Gambar 3. Grafik Hasil Rekapitulasi Uji Lapangan

Setelah melakukan uji perorangan, kelompok kecil, dan lapangan dilakukannya pengambilan respon siswa dan guru. Dimana hasil dari respon siswa yaitu sebanyak 11 siswa memberikan respon sangat baik, dan 11 siswa memberikan respon baik. Sedangkan untuk guru $100 \%$ merespon sangat baik.

Berdasarkan hasil uji yang dilakukan, dapat disimpulkan pengembangan e-modul mata pelajaran administrasi basis data yang telah dibuat menunjukan adanya keberhasilan, dan hal ini terbukti dengan pernyataan siswa yaitu siswa senang menggunakan e-modul dalam pelajaran administrasi basis data dikarenakan e-modul berisikan materi yang jelas (respon siswa) sehingga sudah tersedianya sumber belajar. Terdapat juga pernyataan bahwa dengan adanya $e$ modul, siswa menjadi lebih tertarik belajar administrasi basis data. Dengan demikian e-modul mata pelajaran administrasi basis data dengan model pembelajaran Project
Based Learning berhasil dikembangkan dengan valid.

Selama pelaksanaan penelitian, didapat beberapa kendala saat pengujian e-modul antara lain, adanya gangguan jaringan antar komputer yang menyebabkan koneksi dari server ke client terputus, dan banyak siswa yang membuka situs internet ketika kegiatan pembelajaran berlangsung karena koneksi jaringan terhubung dengan internet. Maka solusi dari kendala yang ditemukan yaitu untuk memastikan jaringan dalam keadaan baik maka perlu dilakukan pengecekan ulang kabel LAN yang terpasang di setiap komputer dan untuk mengantisipasi siswa membuka situs di internet maka lebih baik koneksi internet dimatikan.

\section{SIMPULAN DAN SARAN}

Berdasarkan hasil analisis data dan pembahasan pada penelitian ini, maka dapat diambil simpulan sebagai berikut (1) Implementasi pengembangan e-modul administrasi basis data dilakukan dengan cara melakukan uji produk pengembangan oleh dosen ahli dan uji coba di sekolah serta pengambilan respon siswa dan guru. Tahap uji yang dilakukan oleh dosen ahli yaitu uji ahli isi pembelajaran, uji ahli desain pembelajaran, dan uji ahli isi media. Setelah dilakukan uji ahli, e-modul diimplementasikan di sekolah dengan melakukan 3 tahap uji yaitu uji perorangan dengan mengambil sampel 3 orang, kemudian tahap uji kelompok kecil mengambil sampel 12, dan tahap uji 
lapangan mengambil sampel 22 orang pada kelas XII RPL. Setelah dilakukannya semua uji, diambilnya respon siswa dan guru untuk mengetahui respon mereka mengenai penggunaan e-modul pada mata pelajaran administrasi basis data kelas XII. (2) Berdasarkan respon siswa pada e-modul mata pelajaran administrasi basis data kelas XII dengan model Project Based Learning di SMK Negeri 2 Tabanan, didapatkan rata-rata respon siswa sebesar 65,86 dalam hal kesesuaian tampilan, kemudahan penggunaan e-modul, motivasi terhadap siswa dan isi konten. Jika dikonversikan ke dalam tabel konversi tingkat pencapaian termasuk pada kategori baik. Sedangkan untuk respon guru terhadap $e$ modul didapatkan rata-rata respon sebesar 42 dalam hal kemudahan penggunaan e-modul, antusias siswa, dan pengajaran menggunakan e-modul. Jika dikonversikan ke dalam tabel konversi tingkat pencapaian termasuk pada kategori sangat positif.

Berdasarkan pengamatan penulis di lapangan, terdapat beberapa hal yang dapat dijadikan bahan pertimbangan untuk ditindak lanjuti, yaitu (1) Produk e-modul administrasi basis data dengan model Project Based Learning di SMK Negeri 2 Tabanan yang dikembangkan belum sampai pada tahap pengukuran hasil belajar akhir siswa dengan e-modul. Oleh karena itu, terbuka bagi para peneliti lain untuk mengkaji lebih jauh pengukuran hasil belajar akhir siswa menggunakan $e$ modul ini. (2) Aplikasi moodle harus dibuat dalam bentuk aplikasi instalasi sehingga pada saat penginstalan moodle pada tempat yang berbeda tidak membutuhkan waktu yang lama.

\section{DAFTAR PUSTAKA}

Anwar, I. (2010). Pengembangan Bahan Ajar. Bahan Kuliah Online. Direktori UPI. Bandung.

Dimhad. (2014). Penggunaan E-modul Interaktif Melalui Pembelajaran Berbasis Masalah Untuk Meningkatkan Pemahaman Konsep Sistem Saraf, Kemampuan Generik
Sains Dan Berpikir Kritis http://dimhad13.110mb.com/buku6/a. pdf (diakses tanggal 2 maret 2016).

Fausih, M. (2015). Pengembangan Media E-modul Mata Pelajaran Produktif Pokok Bahasan "Instalasi Jaringan LAN (Local Area Network)" untuk Siswa Kelas XI Jurusan Teknik Komputer Jaringan Di SMK Negeri 1 Labang Bangkalan Madura. 1, 1-9.

Lestari, I. (2013). Pengembangan bahan Ajar Berbasis Kompetensi: Sesuai dengan Kurikulum Tingkat satuan Pendidikan. Padang: Akademia Permata.

Majid, Abdul. (2008). Perencanaan Pembelajaran. Bandung: PT Remaja

Megawati, N. (2010). Pengaruh Pembelajaran Matematika Menggunakan Media CAI (ComputerAssisted Instruction) Dengan Tipe Simulasi Terhadap Motivasi Belajar Matematika Siswa.

Mulyasa, E. (2005). Implementasi kurikulum 2004 panduan pembelajaran KBK. Bandung : PT Remaja Rosdakarya.

Putrayasa, I.B. (2011). Studi Penelusuran Miskonsepsi dalam Pembelajaran Tata Kalimat dengan Model Konstruktivisme Berpendekatan Inkuiri pada Siswa Kleas I SMP Negeri di Kota Singaraja, Kabupaten Buleleng, Provinsi Bali (Prosiding KIMLI, 2011).

Santyasa dan Sukadi. 2007. "Model-Model Pembelajaran Inofatif". Makalah disajikan dalam Pelatihan Setifikasi Guru Bagi Para Guru SD dan SMP di Provinsi Bali tanggal 26-30 Desember 2007, Singaraja : Undiksha.

Tatan, Z. (2012). Pengaruh Penggunaan Media Belajar Dan Minat Belajar Terhadap Hasil Belajar Matematika. Jurnal Formatif 1(1), 70-81.

Wijayanto, M. S. (2014). Pengembangan E-modul Berbasis Flip Book Maker Dengan Model Project based learning Untuk Mengembangkan Kemampuan 
Pemecahan Masalah Matematika. Prosiding Mathematics and Sciences Forum, 625-628.

Zuhdan Kun Prasetyo, dkk. (2011). Pengembangan Perangkat Pembelajaran Sains Terpadu Untuk Meningkatkan Kognitif, Keterampilan Proses, Kreativitas serta Menerapkan Konsep Ilmiah Peserta Didik SMP. Program Pascasarjana UNY. 